\title{
Manajemen Humas Kantor Staf Presiden dalam Mencegah Bahaya Radikalisme di Masyarakat
}

\author{
Yonatan, Daniel Tamburian \\ Yonatan.915150016@stu.untar.ac.id,danielt@fikom.untar.ac.id
}

Fakultas Ilmu Komunikasi Universitas Tarumanagara

\begin{abstract}
This research discuss about the management of Presidential Staff Office's Public Relations in preventing the dangers of radicalism in society. The results of this research are knowing the role of Presidential Staff Office's Public Relations in preventing the dangers of radicalism in society, the programs carried out by Presidential Staff Office's Public Relations, the actions carried out by Presidential Staff Office's Public Relations in counteracting issues of radicalism and terrorism, and various obstacles faced by Presidential Staff Office's Public Relations when providing education or counseling to the community regarding this matter. This research is a qualitative study using a case study method. The theories used in this study are: the role and function of public relations, public relations planning programs, and public relations barriers. The researcher collects data using interviews, observation, literature study, and conducting online information which related to the research.
\end{abstract}

Keywords: Public Relations Role, Government Public Relations, Executive Office of The President, Radicalism, Terrorism.

\begin{abstract}
Abstrak
Penelitian ini membahas tentang manajemen humas atau public relations Kantor Staf Presiden (KSP) dalam mencegah bahaya radikalisme di masyarakat. Hasil dari penelitian ini yaitu peneliti mengetahui peran yang dilakukan humas KSP dalam mencegah bahaya radikalisme di masyarakat, mengetahui program-program yang dilakukan oleh humas KSP, mengetahui perencanaan atau tindakan yang dilakukan humas KSP dalam menangkal isu-isu radikalisme dan terorisme serta hambatan yang didapat oleh humas ketika melakukan penyuluhan kepada masyarakat. Penelitian ini merupakan penelitian kualitatif dengan menggunakan metode studi kasus. Teori yang digunakan dalam penelitian ini yaitu, peran dan fungsi humas, perencanaan program-program humas, hambatan humas atau public relations. Peneliti mengumpulkan data dengan menggunakan wawancara, observasi, studi kepustakaan dan melakukan penelusuran data online yang terkait dengan penelitian.
\end{abstract}

Kata Kunci: Peran Humas, Humas Pemerintah, Kantor Staf Presiden, Radikalisme, Terorisme.

\section{Pendahuluan}

Indonesia merupakan negara kepulauan yang terdiri dari berbagai suku, agama, ras dan antargolongan. Letak geografis Indonesia yang berada di tengah-tengah jalur perdagangan dunia membuat posisi Indonesia sangat strategis dan menjadi rebutan pengaruh kekuasaan negara-negara besar sejak dulu. Sumber daya alam yang melimpah membuat Indonesia menjadi negara yang paling diinginkan oleh setiap negara maju untuk menancapkan kekuasaan dan kekuatan mereka agar mereka bisa 
mengendalikan dan menguasai sumber daya alam Indonesia. Pertarungan kekuatan dan kekuasan negara-negara besar seperti Amerika dan Tiongkok menjadikan negara Indonesia rentan terhadap pergolakan dan pertikaian sosial. Pertarungan negaranegara besar memperebutkan Indonesia tidak hanya seputar kekuasaan dan kekuatan tapi juga ideologi.

Dalam pertarungan ideologi Indonesia mudah dipecah belah dan diadu domba. Hal ini terbukti dari sejarah Indonesia tatkala dijajah Belanda yang menerapkan taktik adu domba. Pertarungan ideologi selalu disertai dengan sikap atau tindakan radikal.Menurut Kamus Besar Bahasa Indonesia radikalisme merupakan paham atau aliran yang radikal dalam politik dimana paham ini menginginkan adanya perubahan atau pembaharuan sosial dan politik melalui cara-cara kekerasan atau ekstrem (Depdiknas,2008:1130). Ciri-ciri dari sikap radikal yaitu pertama intoleran atau tidak menghargai pendapat dan keyakinan orang lain, kedua fanatik atau merasa dirinya benar, ketiga menganggap orang lain salah, keempat eksklusif atau membedakan diri dari umat islam umumnya dan kelima cenderung menggunakan cara-cara kekerasan untuk mencapai tujuan (belmawa.ristekdikti.go.id,2016).

Paham radikalisme merupakan benih lahirnya terorisme. Menurut Kamus Besar Bahasa Indonesia terorisme merupakan tindakan kekerasan yang menimbulkan ketakutan untuk tujuan utama yaitu politik dan praktik tindakan teror (Depdiknas, 2008:1455). Beberapa faktor yang memotivasi seseorang untuk bergabung dalam kelompok terorisme yaitu pertama, merasa kecewa dengan pemerintah karena kondisi negara yang mengalami kemiskinan dan ketidakadilan. Kedua, pengaruh lingkungan luar negeri yang memberikan dorongan tumbuhnya sentimen keagamaan seperti ketidakadilan global, politik luar negeri yang arogan. Ketiga, terkait dengan pemahaman keagamaan dan penafsiran kitab suci yang sempit, serta sikap dan pemahaman yang radikal memotivasi seseorang untuk bergabung dalam jaringan terorisme (belmawa.ristekdikti.go.id,2016).

Di dunia kelompok radikal dan teroris yang sudah diketahui banyak orang yaitu Islamic State in Irak And Syria (ISIS). Beberapa kelompok radikal di Indonesia yaitu: Hizbut Tahrir Indonesia (HTI), Front Pembela Islam (FPI), FPI Pekalongan, FPI Magelang dan FPI Yogyakarta, Forum Komunikasi Aktivis Masjid (FKAM), Front Pemuda Islam Surakarta (FPIS), Front Umat Islam (FUI), Jamaah Islamiyah (JI), Majelis Mujahidin Indonesia (MMI), Jamaah Ansharut Tauhid (JAT) (TIM SETARA Institute,2012:38-40). Di Indonesia kejadian terorisme sudah pernah terjadi berulang kali. Belum lama ini pada pertengahan bulan Mei 2018, serangkaian tindakan terorisme terjadi di Surabaya, dimana ada 3 gereja yaitu Gereja Pantekosta Pusat Surabaya (GPPS) Arjuna, GKI Diponegoro, dan Gereja Santa Maria Tak Bercela dibom oleh kelompok teroris Jamaah Ansharut Daulah (JAD) diketuai oleh Aman Abdurrahman yang terlibat juga kasus bom Thamrin (Merdeka,2018)

Seiring perkembangan zaman, keberadaan internet menjadi bagian penting dalam hidup masyarakat untuk mendapatkan informasi yang diinginkan. Internet memudahkan kelompok radikalisme dan terorisme dalam menyebarkan pahamnya melalui dunia maya kepada sasarannya. Akibat dari tindakan tersebut menimbulkan situasi yang mencekam, rasa takut dan memakan korban yang bersifat massal. Juga dapat memecah belah persatuan dan kerukunan negara Indonesia, dimana bertentangan dan berlawanan dengan ideologi bangsa kita Pancasila. Maka diperlukan tindakan preventif dari pemerintah serta lembaga-lembaga pemerintah yang bertugas untuk mencegah tindakan radikalisme dan terorisme ini. 
Dalam menjalankan tugasnya, lembaga pemerintah dibantu biro hubungan masyarakat (Humas) atau public relations (PR) untuk menyampaikan informasi dan kebijakan lainnya kepada publik. PR adalah bentuk komunikasi yang direncanakan baik itu internal maupun eksternal, antara suatu organisasi dengan semua khalayak untuk mencapai tujuan-tujuan spesifik yang berlandaskan pada saling pengertian (Frank Jefkins,2003:10). Saat ini humas tidak hanya dibutuhkan di perusahaan swasta tetapi juga dibutuhkan di pemerintahan. Shanon A. Bowen menegaskan bahwa humas pemerintah merupakan fungsi komunikasi yang menghubungkan interaksi antara warga dengan pemerintah, dengan aturan, dan perpanjangan tangan kebijakan pemerintah (Suprawoto,2018:48-49). Disamping itu humas pemerintah mempunyai tugas dan peran penting dalam menyampaikan informasi mengenai kebijakan dan tindakan pemerintah serta pencegahan bahaya radikalisme kepada masyarakat. Dari penjelasan diatas, maka penulis ingin meneliti tentang bagaimana manajemen humas Kantor Staf Presiden dalam mencegah bahaya radikalisme di masyarakat.

Penelitian ini juga bertujuan untuk mengetahui bagaimana peran yang dilakukan humas kantor staf presiden dalam mencegah bahaya radikalisme di masyarakat, untuk mengetahui program-program yang dilaksanakan oleh humas kantor staf presiden, untuk mengetahui perencanaan atau tindakan humas pemerintah dalam menangkal isu terorisme, serta untuk mengetahui berbagai hambatan yang didapat oleh humas kantor staf presiden dalam mengedukasi masyarakat akan bahaya radikalisme.

\section{Metode Penelitian}

Pendekatan penelitian yang digunakan oleh peneliti yaitu menggunakan pendekatan penelitian kualitatif. Menurut Moleong (2009: 6) pendekatan penelitian kualitatif adalah penelitian yang memahami fenomena tentang apa yang dialami oleh subjek penelitian misalnya perilaku, persepsi, motivasi dan tindakan lainnya secara holistik dengan mendeskripsikan kata-kata dan bahasa pada suatu konteks khusus yang alamiah dengan memanfaatkan berbagai metode alami.

Jenis penelitian ini adalah deskriptif. Menurut Nazir (2011: 54) deskriptif merupakan suatu metode dalam meneliti status kelompok manusia, suatu objek, suatu set kondisi, suatu sistem pemikiran, ataupun suatu kelas peristiwa pada masa sekarang. Dimana deskriptif ini memiliki tujuan untuk memperoleh pemahaman yang mendalam tentang fakta, mkna dan kenyataan yang relevan. Jadi dalam penelitian kualitatif deskriptif ini membantu penulis menjelaskan, menggambarkan dan mendeskripsikan peran humas kantor staf presiden dalam mengedukasi masyarakat akan bahaya radikalisme.

Dalam penelitian ini peneliti menggunakan metode penelitian yaitu studi kasus. Menurut Emzir (2012: 20) studi kasus merupakan penelitian kualitatif yang berusaha menemukan makna atau arti, menyelidiki proses, dan memperoleh pengertian dan pemahaman yang mendalam dari seseorang, kelompok, atau situasi maupun kondisi.

Pada penelitian ini peneliti melakukan pengumpulan data melalui studi pustaka, observasi, wawancara, dan penelusuran online. Subjek dalam penelitian ini adalah Bapak Agustinus Eko Rahardjo selaku Humas Kantor Staf Presiden yang berlokasi di Jalan Veteran No. 16 Jakarta. Sedangkan objek dalam penelitian ini adalah peran humas kantor staf presiden dalam mengedukasi masyarakat akan bahaya radikalisme. 
Teknik analisa data yang digunakan pada penelitian ini adalah tenik analisis data kualitatif Miler dan Huberman. Menurut Miler dan Huberman (1992) terdapat 3 teknik analisis data yaitu reduksi data, penyajian data, dan kesimpulan atau verifikasi (Gunawan, 2014: 210-211). Peneliti menggunakan teknik triangulasi yaitu triangulasi dengan sumber data sebagai teknik keabsahan data pada penelitian ini.

\section{Hasil Temuan dan Diskusi}

Hasil temuan dan diskusi ini akan peneliti paparkan menjadi beberapa subpembahasan. Berikut dibawah ini:

a. Radikalisme di Indonesia.

Berdasarkan hasil wawancara dengan Agustinus Eko Rahardjo selaku Humas Kantor Staf Presiden bagian Tenaga Ahli Madya. Bahwa saat ini paham radikalisme sudah cukup mengancam, karena sudah memasuki ke tingkat pelajar seperti sekolah, universitas dan kalangan anak muda atau biasa dikenal kaum milenial dengan berbagai cara. Walaupun secara resmi pemerintah telah membubarkan kelompokkelompok seperti HTI dan lainnya. Tetapi sel-sel seperti itu masih kuat. Contohnya kasus di Mako Brimob Kelapa 2 Depok, dimana terjadi kerusuhan dan beberapa hari kemudian muncul terjadinya ledakan bom di Surabaya, sehingga kelompokkelompok tersebut terbilang masih banyak dan pemerintah pun menganggap mereka itu masih kuat, maka harus tetap melakukan kewaspadaan ekstra terhadap radikalisme, ekstremisme, dan terorisme agar tidak berkembang.

b. Peran Humas Kantor Staf Presiden dalam mencegah bahaya radikalisme di masyarakat.

Peran humas atau public relations dalam praktek komunikasi sehari-hari pada sebuah perusahaan menurut Dozier dan Broom (1995) sebagaimana yang dikutip (Ruslan,2012: 20) terbagi menjadi empat kategori antara lain: Penasehat Ahli (Expert Prescriber dimana sebagai seorang penasehat ahli public relations KSP memberikan informasi yang akurat kepada pemerintah dalam hal ini presiden mengenai masalah radikalisme dan terorisme, seperti yang dikatakan oleh Pak Jojo dalam hasil wawancara yaitu Presiden mendesak DPR untuk melakukan perubahan undangundang terorisme. Dan juga pemerintah bersikap tegas dalam melakukan hal itu. Fasilitator Komunikasi (Communication fasilitator) yaitu humas KSP juga berperan sebagai fasilitator komunikasi yang dimana menjadi komunikator dalam menegah terkait bahaya radikalisme dan terorisme kepada masyarakat. Seperti yang dikatakan oleh Pak Jojo bahwa pemerintah menegaskan kepada masyarakat khususnya anak muda sekarang ini, untuk bersikap toleran, pluralis, serta menghargai perbedaanperbedaan yang ada di Indonesia. Fasilitator Proses Pemecahan Masalah (Problem solving process fasilitator) juga humas KSP membantu dalam proses pemecahan masalah yang ada di Indonesia yaitu radikalisme dan terorisme. Dimana humas KSP berusaha untuk mengambil tindakan untuk mengatasi krisis atau masalah radikalisme ini, dengan mengadakan seminar-seminar, berdiskusi ke masyarakat, mendatangi pesantren. Serta humas atau public relations KSP berusaha untuk menyediakan layanan komunikasi berbasis media sosial, dimana menerima pengaduan masyarakat, pendapat atau aspirasi dari masyarakat mengenai isu radikalisme. Berikut peneliti melakukan observasi mengenai layanan KSP tersebut yang terdapat pada situs resmi KSP yaitu Layanan Aspirasi Dan Pengaduan Online Rakyat (LAPOR), Teknisi Komunikasi (Communication technician) dimana humas KSP juga melakukan 
peranan seperti melakukan kontak dan berhubungan dengan media serta mengelola situs resmi ksp.go.id dan presidenri.go.id

c. Perencanaan dan Program Humas Kantor Staf Presiden.

Sesuai dengan peranannya humas sebagai pengabdi untuk kepentingan masyarakat, juga sebagai mediator antara pimpinan dengan publik serta dokumentator sehingga program-program humas dititiberatkan (Widjaja, 2010:61) yaitu:

1. Program Pelayanan

Program ini merupakan layanan data atau informasi baik secara lisan atau tertulis, termasuk penyelenggaraan display tetap dan pameran. Dalam hal ini program yang dilakukan humas KSP yaitu mengadakan seminar-seminar, berdiskusi ke masyarakat, mendatangi pesantren untuk memberikan pemahaman mengenai radikalisme dan terorisme. Berikut peneliti mengumpulkan data dari berita online yang berkaitan dengan humas KSP dalam melaksanakan programnya.

Gambar 1. Presiden Jokowi ajak masyarakat lawan intoleransi, radikalisme dan terorisme

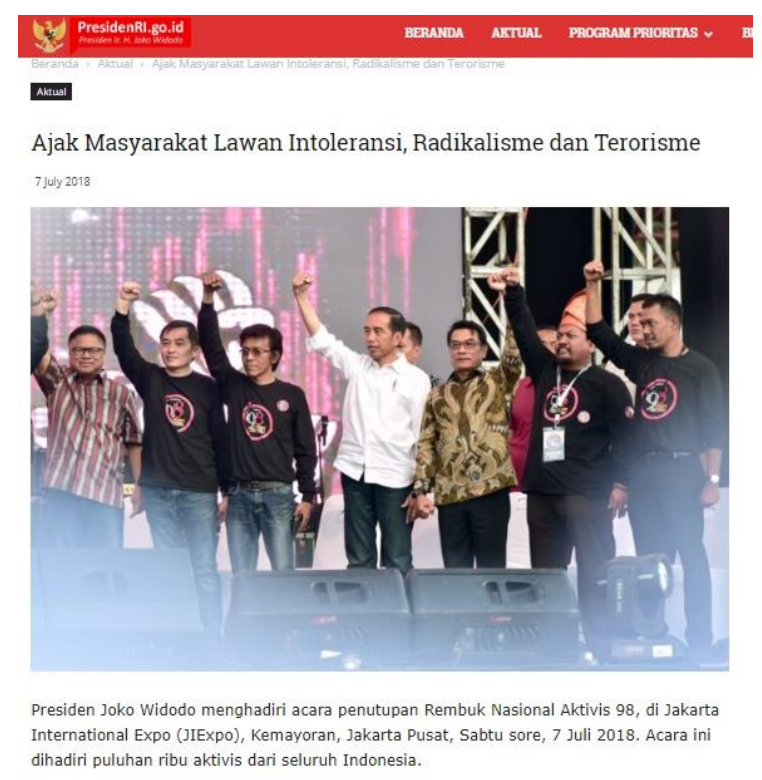

(Sumber: http://presidenri.go.id/berita-aktual/ajak-masyarakat-lawanintoleransi-radikalisme-dan-terorisme.html)

\section{Program Mediator}

Program ini merupakan penerbitan berbagai media massa, penyelenggaraan konferensi pers, wisata pers, menjawab surat pembaca, menanggapi tajuk rencana atau surat kabar yang negatif. Seperti yang pernyataan dari Bapak Jojo bahwa humas KSP menanggapi atau meresepon berita atau hal yang negatif. Seperti Bapak Jokowi yang diisukan PKI. Berikut peneliti mengumpulkan data yang berkaitan dari media atau berita online. 
Gambar 2. Jokowi Silaturahmi di Pondok Pesantren BUGEN AL-ITQON

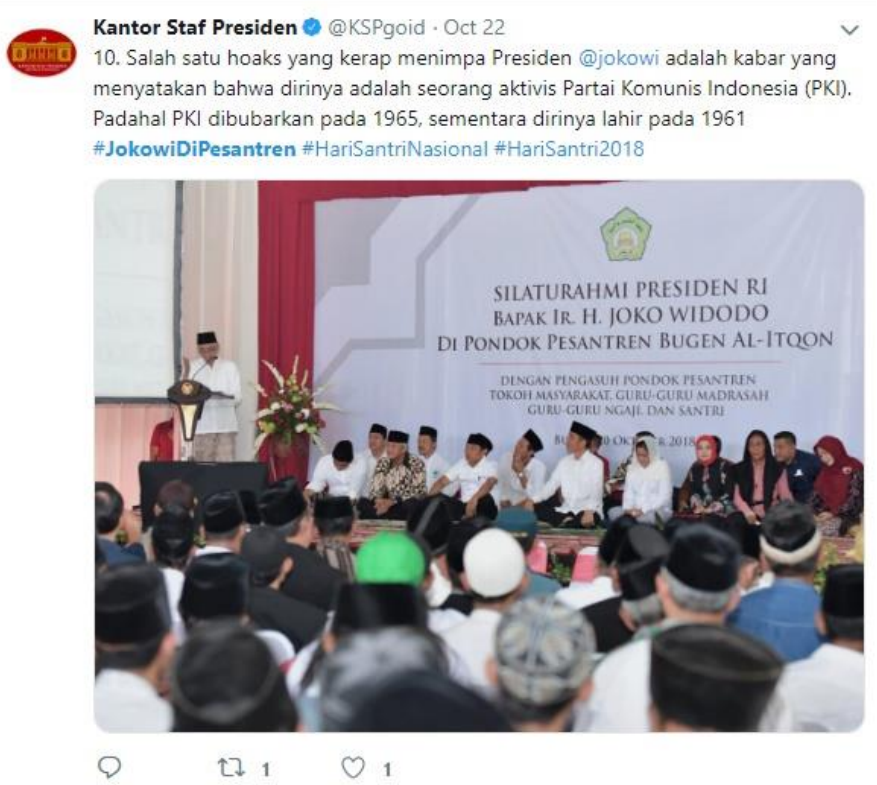

(Sumber: https://twitter.com/KSPgoid )

\section{Program Dokumentator}

Program ini berupa pembuatan dokumentasi film, foto, rekaman (kaset audio dan video), transkrip pidato dan lain-lain. Dalam hal ini salah satu program yang dilakukan humas KSP, seperti yang Bapak Jojo katakan bahwa dengan mengadakan lomba-lomba membuat film, vlog serta blog untuk masyarakat terutama yang harus dijangkau saat ini milenial.

Setelah melaksanakan berbagai program-program yang dibuat, selanjutnya perencanaan yang dilakukan humas KSP dalam menangkal isu radikalisme maupun terorisme ini yaitu, pihak KSP melakukan kerja sama dengan Badan Nasional Penanggulangan Terorisme (BNPT) maupun Sibereskim Mabes Polri untuk melakukan pembasmian isu-isu radikalisme yang beredar, juga melakukan pendekatan khusus kepada kelompok-kelompok yang kurang pengetahuan atau pemahaman soal radikalisme dan terorisme serta melakukan klarifikasi bahwa isu yang beredar tidak benar (hoax). Hal ini dibuktikan melalui hasil wawancara dengan narasumber Bapak Jojo. Juga peneliti melakukan pengumpulan data hasil observasi melalui pemberitaan online yang berkaitan dengan hal tersebut, salah satunya yaitu situs resmi ksp.go.id.

d. Hambatan yang didapat oleh Humas Kantor Staf Presiden dalam memberikan edukasi kepada masyarakat akan bahaya radikalisme.

Dalam melaksanakan program-program yang ditujukan kepada semua masyarakat. Terdapat hambatan-hambatan dalam melakukan perencanaan program public relations sebagai berikut: Humas KSP pun memberikan pernyataan dari Bapak Jojo bahwa mendapati beberapa kendala atau hambatan-hambatan dalam mengedukasi masyarakat. Dalam hal ini, narasumber menyatakan bahwa hambatan tersebut yaitu penyampaian pemahaman radikalisme dan terorisme kemasyarakat menengah kebawah, seperti yang tinggal dipedalaman dan pelosok-pelosok, dimana minimnya pengetahuan, keterbatasan alat komunikasi yang dimiliki masyarakat tersebut dalam menerima informasi. Sehingga perlu adanya usaha lain untuk 
mengatasi kendala tersebut, seperti yang dikatakan oleh Bapak Jojo yaitu dengan berusaha membuat film pendek, mengadakan seminar, memberikan penyuluhan tentang bahaya radikalisme dan terorisme serta membuat brosur dan flyer lalu berbagai cara seperti tatap muka. Berdasarkan pernyataan dari narasumber Bapak Jojo, peneliti menyimpulkan bahwa teori ini tidak berkaitan karena peneliti mendapatkan penemuan baru dari pernyataan narasumber.

\section{Simpulan}

Terdapat peran yang dilakukan Humas Kantor Staf Presiden (KSP) dalam mencegah bahaya radikalisme di masyarakat yaitu dengan menegaskan kepada masyarakat untuk bersikap toleran, pluralis serta menghargai perbedaan melalui konten-konten maupun berita-berita sejuk di berbagai media sosial seperti facebook,twitter, instagram, situs resmi jalandamai.org, ksp.go.id, dan presidenri.go.id.

Program-program yang dilaksanakan oleh humas KSP dalam mencegah bahaya radikalisme di masyarakat yakni melaksanakan program diantaranya dapat melayani masyarakat, menjadi mediator, serta dokumentator kepada semua segmen masyarakat Indonesia terutama kalangan anak muda.

Tindakan atau langkah yang dilakukan humas pemerintah yakni KSP dalam menangkal isu terorisme dengan melakukan kerjasama dengan BNPT serta lembagalembaga yang bertanggung jawab dalam membasmi isu-isu yang beredar dimasyarakat.

Serta berbagai hambatan atau kendala yang didapat Humas KSP ketika memberikan edukasi atau penyuluhan kepada masyarakat terutama masyarakat menengah kebawah, kepedalaman dan pelosok-pelosok yang sulit dijangkau daerahnya terkait hal tersebut. Juga kendala lain, minimnya alat komunikasi yang dimiliki masyarakat tersebut dalam menerima informasi mengenai radikalisme dan terorisme serta kurangnya kesadaran masyarakat terhadap paham tersebut.

\section{Ucapan Terima Kasih}

Ucapan terima kasih penulis berikan kepada narasumber yang telah meluangkan waktunya dan memberikan informasi kepada peneliti selama proses pengumpulan data dalam penelitian ini. Peneliti juga ingin mengucapkan terima kasih kepada dosen pembimbing serta Fakultas Ilmu Komunikasi Universitas Tarumanagara.

\section{Daftar Pustaka}

Belmawa.Ristekdikti.go.id.(2016). Strategi Menghadapi Paham Radikalisme dan Terorisme (http://belmawa.ristekdikti.go.id/wp-content/uploads/2016/12/Strategi-MenghadapiPaham-Radikalisme-Terorisme.pdf, diakses pada 16 September 2018 pukul 20:51 WIB)

Emzir. (2012). Metodologi Penelitian Kualitatif: Analaisis Data/Emzir Edisi 1, Cetakan 4 Jakarta : Rajawali Pers.

Gunawan, Imam. (2014). Metode Penelitian Kualitatif Teori dan Praktik. Jakarta: PT Bumi Aksara.

Jefkins, Frank (2003). Public Relations, Edisi Kelima. Jakarta: Erlangga 
Departemen Pendidikan Nasional. (2008). Kamus Besar Bahasa Indonesia Pusat Bahasa, Edisi Keempat Jakarta: Gramedia Pustaka Utama

MerdekaNews.(2018). Kenapa Rangkaian Bom teror Bom terjadi di Surabaya, begini penjelasan Kapolri.

(https://www.merdeka.com/peristiwa/kenapa-rangkaian-teror-bom-terjadi-di surabaya-begini-penjelasan-kapolri.html), diakses pada tanggal 16 September 2018 pukul 23:52)

Moleong, Lexy J. (2009). Metodelogi Penelitian Kualitatif. Edisi Revisi. Bandung: PT Remaja Rosdakarya Offset.

Nazir, Moh. (2011). Metode Penelitian. Bogor: Ghalia Indonesia.

Ruslan, Rosady. (2012). Manajemen Public Relations dan Media Komunikasi. Jakarta: Rajagrafindo Persada

Suprawoto (2018). Government Public Relations. Perkembangan \& Praktik di Indonesia. Jakarta: Prenadamedia Group

Tim Setara Institute. (2012). Dari Radikalisme Menuju Terorisme Studi Relasi dan Transformasi Organisasi Islam Radikal di Jawa Tengah \& D.I. Yogyakarta. Jakarta: Pustaka Masyarakat Setara

Widjaja, H.A.W. ( 2010). Komunikasi dan Hubungan Masyarakat. Jakarta: Bumi Aksara. Jakarta: PT Rajagrafindo Persada. 